\title{
Rwanda's gendered agricultural transformation: a mixed-method study on the rural labour market, wage gap and care penalty
}

\author{
Christine Bigler - Michèle Amacker - Chantal Ingabire - Eliud Birachi
}

Interdisciplinary Centre for Gender Studies (ICFG),

University of Bern, Mittelstrasse 43, 3012 Bern, Switzerland.

Corresponding author: christine.bigler@izfg.unibe.ch

\begin{abstract}
Rwanda's Vision 2020 neoliberal development policy focuses on socio-economic transformation with a specific focus on the agriculture sector and gender equality. Through the commercialization of agriculture, employment opportunities inside and outside the sector are expected to be created. Both women and men are integrated into this new agriculture production system. Based on a mixed-method approach, this paper provides insights into current transformations of the rural labour market in Rwanda. The feminization debates build the theoretical background. The empirical results show that wage employment is created almost exclusively in the informal sector, typically for casual on-field agriculture workers. The drivers of casual on-field agricultural work are land scarcity and low agriculture commercialization, as well as gender, age and household size. It is apparent that for the same work, women earn approximately 20 percent less than men. Women play an important role in the rural labour market, especially as self-employed farmers and on-field agriculture workers. At the same time, they perform the bulk of reproductive work and must perform under precarious work conditions for low wages. The Rwandan agricultural transformation is gendered, and due to reproductive work, women do not have the same opportunities in the paid rural labour market.
\end{abstract}

\section{Introduction}

The rural labour market, especially with regard to rural wage employment, has recently garnered worldwide interest. Through continuous commercialization of agriculture, as well as ongoing population growth and an increase in land scarcity, rural wage employment is becoming increasingly more important (Headey and Jayne 2014; Holden and Otsuka 2014; Pritchard 2013). Globally, almost half of the population lives in rural areas. In sub-Saharan Africa, the rural population accounts for over 60 
percent of the total, and in Rwanda, the number is over 70 percent (World Bank 2016a). As globalization has grown, more women have been integrated into the paid labour market in sub-Saharan Africa (International Labour Organization (ILO) 2016). However, they still perform the bulk of unpaid and reproductive labour. This leads to a gender segmentation of the labour market (Razavi et al. 2012).

Internationally, due to the 2030 Agenda for Sustainable Development, unpaid care work and decent work for women and men have moved closer to the focal point of the international aid and research agenda (United Nations 2015). However, the African rural labour market is fragmented, and few studies have been carried out (Oya and Pontara 2015). So far, investigations have confirmed that women are overrepresented in low income and informal work arrangements in East Africa's non-traditional export industries (Barrientos, Dolan and Tallontire 2003; Food and Agricultural Organization (FAO) and International Fund for Agricultural Development 2011; ILO 2010). Similarly, women are employed as casual on-field agricultural workers by wealthier households or more commercialized farmers in Rwanda (Ansoms 2010; Petit and Rizzo 2015). The rural livelihood is complex; most small-scale farmers still pursue multi-strategy livelihoods, which means they do self-employed farm work as well as pursue wage employment, mostly on a daily or seasonal basis (FAO and International Fund for Agricultural Development 2010; Oya and Pontara 2015). Official statistics typically use simple tools that are not able to capture the complexity of rural livelihoods. Because official statistics on rural employment are often incomplete and the participation of women is often underestimated, additional research is required (Oya 2013; Doss 2011).

Previous research on rural wage employment has focused exclusively on income-generating activities and has not included reproductive work, which is essential for a gender-sensitive analysis of the labour market (Hirway and Jayne 2015). Moreover, social and economic transformations are taking place simultaneously and therefore must be addressed together (Perrons 2015). In response to the research gap, this paper follows up on previous related discussions but goes further. The purpose is to map the rural labour market of the Northern Province of Rwanda from a more holistic perspective with a mixedmethod approach, where self-employed farming, wage employment, and reproductive work are taken into account. This is a unique strategy for Rwanda, since such detailed data have not been available for this context.

To understand the complexity of the socio-economic transformation and the rural labour market from a gender perspective, it is necessary to begin with a discussion of the ongoing and controversial feminization of poverty ${ }^{1}$. Especially in the scientific field of development studies, this discussion has

\footnotetext{
${ }^{1}$ The term feminization of poverty focuses on gender differences in poverty rates. Feminization describes both the unequal state of men's and women's poverty rates and the processes by which women's risk of poverty has increasingly exceeded that of men's (McLanahan and Kelly 2006).
} 
stimulated further feminist debates - among others, the feminization of the labour market, the feminization of agriculture, and the feminization of responsibilities and obligations. This discussion has stimulated further feminization debates, especially in the scientific field of development studies (Pearce 1978; McLanahan und Kelly 2006; Chant 2006; Momsen 2008; Chant 2010). Three debates are at the focus of the analysis: the feminization of the labour market, the feminization of agriculture, and the feminization of responsibilities and obligations. Based on empirical data from the Northern Province of Rwanda, these three debates are critical as we examine the rural labour market in this region in depth.

\subsection{State-driven agriculture transformation and the rural labour market}

A small, mountainous, landlocked country (Antonites and Haguma 2011), Rwanda has an equatorial climate and the highest population density in Africa (Huggins 2014a). Approximately 72 percent of the inhabitants are employed in the agricultural sector, contributing 33 percent of the GDP and making this sector the backbone of the economy (World Bank 2016b). Good climate and topographical conditions make Rwanda's agricultural sector a major player in economic expansion and a key to sustainable development and the improvement of livelihoods (Booth and Golooba-Mutebi 2014). The World Bank (2013) describes increasing agricultural productivity as the main driving force for the Rwandan economic growth that has taken place during the last decade. Rwanda's economy grew at a rate of 7.1 percent on average from 2011 to 2014 (World Bank 2016c). With this growth, it is not surprising that the Government of Rwanda (GoR) focuses on agriculture policies.

In 2000, the "Rwanda Vision 2020" programme was launched. One of the pillars of this vision is to lead subsistence-oriented agriculture into a productive, high value, market-oriented agriculture (Republic of Rwanda 2000). To reach this goal, the government of Rwanda formulated the "Strategic Plan for the Transformation of Agriculture" and the "Crop Intensification Program (CIP)." Rapid growth of the agriculture sector through commercialization is the main intention of CIP. The policy focuses on the selection of crops, the shift from inter-cropping to mono-cropping, and the use of quality inputs and land consolidation (Huggins 2014a; Clay 2017). The government works through agriculture cooperatives to reach small-scale farmers, and cooperative members benefit from subsidized inputs and training (Republic of Rwanda 2012b; Republic of Rwanda 2013a; Verhofstadt and Maertend 2014; Ansoms et al. 2017). Cooperative membership has a positive impact on a farm household's income level, but poor farmers with limited access to land and finances are excluded and do not have the opportunity to profit from government subsidies (Verhofstadt and Maertens 2015). According to Huggins (2014a), cooperatives are also seen as the government's long arm, and only farmers who adhere to the given programme benefit fully. Rwanda follows a neoliberal approach, where subsistence-oriented agriculture 
production is seen as underdeveloped and economy of scale and export-oriented agriculture production are the goals for prosperity and poverty reduction (Ansoms and Claessens 2011; Huggins 2014a; Tobias and Mair 2013). The government of Rwanda argues that this process should go hand in hand with employment creation inside and outside the agriculture sector (Republic of Rwanda 2013b).

The present agriculture policies, especially the CIP, are criticized by different researchers. Some note that only a small part of the population is profiting from this transformation because the expected employment creation is limited, especially outside the primary sector (Ansoms et al. 2017; Cioffo, Ansoms and Murison 2016). Huggins (2014a) and Lund (2016) argue that Rwanda's agricultural policies are effective for some crops because the yield has tripled, but at the same time, small-scale farmers are depending more on food purchases and market forces, which leads to greater vulnerability. Cioffo, Ansoms and Murison (2016) go a step further and indicate that the CIP has a negative effect on small-scale farmers in other ways: First, poorer farmers with less access to quality inputs do not profit in the same way as medium- and higher-income farmers. Second, the mainly top down implementation of the programme faces some bureaucratic obstacles, and this has a negative impact on ecological and social sustainability. According to Dawson, Martin and Sikor (2016), only a small and wealthy group profits from the current agricultural policies; landless and poorer households do not benefit from this green revolution. Therefore, Cioffo, Ansoms and Murison (2016) conclude that CIP generates disparities. Furthermore, Ansoms et al. (2017) show that there is a mismatch between the government's expectations in terms of the effectiveness of the agricultural production, the related pressure on the small-scale farmers and the realities at the local level. Lund (2016) notes that when small-scale farmers are told how and what to cultivate, various forms of resistance may occur in the transformation process. Diao, Hazell and Thurlow (2010) promote alternative growth strategies rather than the commercialization of a small-scale farmer's household in Africa, especially because agricultural-led growth has failed in many African countries. Huggins (2014a) notes that the Rwandan agricultural policy was not tested extensively in the field and that the priority crop programme was implemented after only a short testing phase. Connected with the fact that women are mainly in charge of household food security and stable food production, the transformation to priority crops, which are mostly cash crops, has had a direct impact on women's lives (Doss 2002). However, the political effort of the Rwandan government aims not only to intensify agricultural production but also to integrate into the export market, especially with the new export crops. However, this appears to be difficult. While the Rwandan government gives significant attention to international and regional investors in commercial agricultural businesses by establishing entrepreneur-friendly conditions, such as infrastructure and appropriate legislations (Booth and Golooba-Mutebi 2014), the export of horticultural crops declined in 2015 (National Agricultural Export Development Board 2015). 
Furthermore, the Rwandan population is still growing (World Bank 2016b), and there is a higher demand for non-agricultural employment. In fact, every year, 200,000 jobs should be created to integrate the youth into the labour market (Republic of Rwanda 2013). According to the newest "Poverty Profile Report 2013/2014,” only 90,000 jobs were created between 2011 and 2014 (Republic of Rwanda 2015b). Twice as many jobs are created in rural areas compared to those created in urban areas. These figures reflect only formal employment; no reliable figures are available for the informal sector. Employment creation in rural areas is crucial for sustainable development, especially with the focus on access to land and the distribution of land. In Rwanda, the availability of employment is restricted as well as access to land. Land is a limited resource in Rwanda, and the average landholding per household decreased from 1.2 hectares in 1980 (Jayne, Chamberlin and Headey 2014) to 0.7 hectares in 2006 (Ansoms and Rostagno 2012; United Nation Conference on Trade and Development 2014) and then to 0.59 hectares per household in 2013 (Republic of Rwanda 2013b). According to Ansoms (2007), Holden and Otsuka (2014) and Pritchard (2013), the inequality in the distribution of land has also grown. Holden and Otsuka (2014) also specified that it is difficult to secure a livelihood if the landholding is smaller than 0.25 to 0.5 hectares. Therefore, intercropping is a way to minimize the risk of rain-fed agriculturebased livelihoods, but this production system runs counter to the current agricultural policies (Holden and Otsuka 2014; van Damme, Ansoms and Baret, 2014; Ansoms and Claessens 2011). With every generation, the landholding decreases, and young people are increasingly pushed out of agriculture into the paid labour market (Ansoms and Claessens 2011; Rizzo 2011).

Since Rwanda is the most densely populated country in Africa, the agricultural outputs are low compared to other countries, and there is no possibility for land expansion (Jayne, Chamberlin and Headey 2014; Holden and Otsuka 2014). This might be one reason why the CIP focuses on agricultural intensification. The current situation is a product of past circumstances and political decisions in terms of land use, as mentioned above. Land use and land inheritance patterns have changed over the different historical periods of Rwanda, which was discussed in the different scales controversy (Huggins 2014b). The topic of population growth in relation to land or environmental sustainability has been discussed widely by scientists and policymakers for decades, and there is no direct connection between them (Detraz 2017; Dawson, Martin and Sikor 2016). This paper will not contribute to that discussion in detail. The complexity of this field calls for a gender perspective, which opens up some alternatives to simplistic and deterministic population growth narratives. Relevant factors such as the infant mortality rate, children as a labour force, caregivers for elderly persons, the preference for sons over daughters, discrimination against women, and the overall social, economic and political conditions must be taken into account (Detraz 2017). 


\subsection{Pushing social transformation through gender-sensitive policies}

Rwanda's state-driven transformation goes beyond economic interests. The government also pushes social transformation through women-friendly politics (Burnet 2011). In the post-conflict phase until 2003, the women's movement and civil society organization achieved important gains in improving women's rights. One major step forward for gender equality was the 1999 inheritance law, which gives women and men the same right to inherit and own land. Another step was adding work regulations for pregnant and breastfeeding women. In addition, the 2003 constitution placed gender equality at its centre (Ayalew, Deininger and Goldstein 2014; Bauer and Burnet 2013; Burnet 2011; Debusscher and Ansoms 2013; GoR 2009a). With the new constitution, a gender quota in all decision-making organizations from the national to the grassroots level has been introduced such that, at the present time, Rwanda has more women than men in the parliament. These turnovers have empowered women to enter other spheres of Rwandan society, especially in urban areas. Women in rural areas participate also in unpaid governmental roles. This has given them more respect but also a heavier workload (Bauer and Burnet 2013; Burnet 2011; GoR 2009a). However, this represents a fundamental change. Before the genocide of 1994, women's formal influence in the government of Rwanda and their involvement in economic activities outside the household were limited (Sharlach 1999). After the 2003 elections, when the current government assumed leadership, equality between women and men continued to be at the centre of national development. In all development policies, gender is mainstreamed ${ }^{2}$, and in 2009, the law to prevent and punish gender-based violence (law 59) became effective (GoR 2008; Ansoms and Rostago 2012). In this law, the protection of pregnant women and women on maternity leave is well noted, in which it is forbidden to cancel a work arrangement in the two cases (GoR 2008). The new labour law introduced in 2009 must be seen as complementary to law 59 but as a setback in terms of gender equality to the previous version. The full-wage replacement for maternity leave was cut back from twelve to six weeks and the weekly working days increased from 5 to 6 days and working hours from 40 to 45 hours (GoR 2009b). In 2015, the cabinet again expanded maternity leave for civil servants to twelve weeks fully paid, but this has not yet been implemented (GoR 2015). Furthermore, the current labour law protects workers against discrimination on grounds of their sex, marital status, or family responsibilities (GoR 2009b).

In terms of international comparisons, Rwanda is performing well in gender equality. According to the World Economic Forum (2016), which annually prepares the “The Global Gender Gap Index”, Rwanda ranks fifth out of 144 countries, higher than many western countries such as Switzerland, Germany, or Denmark. The index indicates the relative disadvantage of women, which is classified in four categories (sub-index): economical participation and opportunity, political empowerment, education attainment,

\footnotetext{
${ }^{2}$ According to ECOSOC (1997: 3), mainstreaming gender is "the processes of assessing the implications for women and men of planned action, including legislation, polices or programmes, in all areas and levels."
} 
and health and survival. Rwanda is ranked in the top ten in political empowerment and has strong performance in economic participation (ranked $8^{\text {th }}$ ). Compared to 2014, Rwanda has closed its genderwage gap and is ranked as the best country worldwide. However, this ranking must be critically evaluated ${ }^{3}$. These data on wage equality are based on the survey question "In your country, for similar work, to what extent are the wages for women equal to those of men?" and not on an actual comparison of wages between men and women (World Economic Forum 2015a; World Economic Forum 2015b).

In conclusion, it can be said that the government of Rwanda plays a major role in ongoing socioeconomic transformation, and this influences women's and men's participation in the rural labour market. Through current agriculture policies, the production of agricultural goods has increased. However, the population as a whole has not had the opportunity to profit from this transformation, especially the landless and poorer farmers, who are being left behind. The gender-mainstreamed policies and the women-friendly politics are paving the way for gender equality in economic and social spheres, which is reflected in big-data analyses such as the gender gap index. However, if and how this political push for social transformation will reach the grass-roots level is still unclear.

\section{The feminization debates}

The ongoing feminization debates build the backbone of this paper, allowing reflection on the socioeconomic transformation and the rural labour market with a gender perspective. This theoretical foundation is the starting point of this research and provides an opportunity to embed the empirical data. The entry point into the feminization debates starts with the controversial discussion about the term "feminization of poverty". Pearce (1978) used the term to show the increasing proportion of women and children among the poor in the U.S. in the 1970s. The term "feminization of poverty" focused attention on gendered poverty rates and the fact that economic inequality between women and men has grown between the years 1950 and 2000 (McLanahan und Kelly 2006). The term strongly influences gender and development discussions, especially during and after the Fourth World Conference on Women in Beijing 1995 (Chant 2010). This discussion about women's economic disadvantages, especially in relation to the development context, was not new, but this phenomenon was discussed as part of the ongoing globalization and the assumption that women comprise 70 percent of the world's poor (Chant 2010). The term feminization of poverty has been critiqued widely. Chant (2006) opines that women, on the one hand, are described as a homogenous group and, on the other hand, are placed at the bottom of household hierarchies; he also states that the important link between men and gender relations is neglected. Chant and Sweetman (2012) add that women are seen as a production factor for more effective development outcomes. Chant (2006) expresses some critical views on the feminization

\footnotetext{
${ }^{3}$ See Jervem (2013).
} 
debate's over-emphasis on female-headed households and on income while neglecting the topic of men and gender relations. She noted the trend of women's diversification and intensification of work versus men's decline of inputs, the persistence gap between women's and men's capacities to negotiate obligations and entitlements in the household, and the mismatch between the investment of women to secure the household's livelihood and the output they receive. Out of the feminization of poverty debates, other spheres of interest have been seen in the light of feminization, such as the labour market, agriculture, and the division of labour. A feminization process is occurring when women become more involved in traditional male activities, such as paid labour, agricultural work, or securing a household's livelihood (Razavi et al. 2012). The results of this paper are analysed under the three principal feminization debates: feminization of the labour market, feminization of agriculture, and feminization of responsibility and obligations.

As a result of industrialization and globalization processes, women's integration into the wage labour market increased between 1980 and 2008 (World Bank Group 2009; Razavi et al. 2012; Kabeer and Natali 2013). This rise in the female proportion of employment has been explained for decades as 'feminization of the labour market' (Tejani and Milberg 2016; Kabeer and Natali 2013; World Bank Group 2009). However, the global labour market participation of both women and men has decreased over the past few years (ILO) 2016), and in some countries and some sectors, a defeminization trend has even been recognized (Tejani and Milberg 2016). In sub-Saharan Africa, a different trend was found: over the last 20 years, female labour market participation rates have risen 3.2 percentage points, and the share of informal employment is higher for women than for men (ILO 2016). Worldwide, informal, precarious, and unprotected forms of work have increased. At the same time, there is a gendered segmentation of the labour market and gendered inequalities in earnings. These are phenomena that are occurring simultaneously with the feminization of the labour market (Kabeer 2012; Razavi et al. 2012).

Agriculture remains the main source of rural employment in sub-Saharan Africa, as well as in Rwanda (FAO 2010), where more than 60 percent of all female workers work in agriculture (ILO 2016; National Institute of Statistics of Rwanda (NISR) 2014). This leads to the feminization of agriculture debates. This expression describes the overrepresentation of women in agriculture and is the case for sub-Saharan Africa. The process of feminization is visible in two different parts of agriculture: self-employed farming and high-value, export-oriented agribusinesses (Doss 2011; Lastarria-Cornhiel 2006; Deere and Doss 2005).

Self-employed farming is the most common form of employment in sub-Saharan Africa, and women are more likely than men to become small-scale farmers (FAO 2010). Traditionally, women are involved in agricultural production as unpaid family labour and are responsible for stable crop production and family food security. However, at the same time, they are excluded from cash crop production 
(Barrientos, Kabeer and Hossain 2004; Boserup 1970). With the increased absence of men through migration and/or off-farm employment, the phenomenon of rural female principal farmers has appeared (Razavi 2009). Rural women manage their households and pursue productive and reproductive labour work to secure their livelihoods (Doss 2011).

In addition, the commercialization of agriculture and the global agricultural trade have become more important over the past three decades. Africa's high-value, non-traditional agricultural products have increased from 2.36 billion USD in 1980 to 11.59 billion USD in 2010 (Maertend and Swinnen 2015). In some East African countries, this high-value, export-oriented value chain has emerged as a significant source of rural employment for women (Doss 2011; FAO 2010). However, this labour market is highly gendered, and women are mostly found in precarious employment situations. In the Ugandan and Kenyan cut-flower industries, 75 to 85 percent of the employees are women, and they work mostly on an informal basis with no social security and low wages (Razavi 2011; Barrientos, Kabeer and Hossain 2004; Barrientos, Dolan and Tallontire 2003; FAO 2010). On one hand, Rwanda’s formal, high-value, non-traditional agriculture export sector remains small (Booth and Golooba-Mutebi 2014) compared to neighbouring countries and the traditional export crops (NAEB 2013; Golub and McManus 2008). In 2013, Rwanda exported fruits and vegetables worth 9.8 million USD; this is only 1.5 percent of all commodities exported in 2013 (NAEB 2013; United Nation Comtrade and United Nation Trade Service 2015). On the other hand, Rwanda has an active but scattered informal cross-border trade with a high share of female traders (Titeca and Kimanuka 2012). Wage employment in Rwanda's rural areas is important for securing rural livelihoods, and women are integrated into agriculture mostly as casual workers and are employed by wealthier farmers (Petit and Rizzo 2015; Ansoms 2010).

In addition, women are entering into the paid labour market or taking over men's duties in rural households while at the same time being mainly responsible for unpaid reproductive labour (Doss 2011). This leads to a heavy workload and time constraints for women (Brauw, Mueller and Lee 2014). Chant (2014) described this phenomenon as the "feminization of responsibility and obligations."

\section{Method and research setting}

With this understanding, the central objective that motivates this paper is to map the rural labour market and to demonstrate the socio-cultural, economic, and regulatory factors influencing women's and men's employment. This research is part of a larger study on the impact of the economic and social transformation process in the Northern Province of Rwanda. In this study, an "Explanatory Sequential Mixed Method Design” was used (Creswell 2014). This approach has been chosen for three reasons: First, little was known about the rural labour market in Rwanda and the impact of the state-driven agricultural social transformation process, especially with a gender focus. Second, the results need to be representative. Third, a mixed-method approach offsets the weaknesses of both qualitative and 
quantitative research and opens up the possibility for multiple perspectives, which is needed to fully capture all dimensions of precarious employment (Creswell and Clark 2011; Kuckartz 2014; Siegmann and Schiphorst 2016). Furthermore, a qualitative approach is appropriate in a post-conflict country such as Rwanda, where the context is highly politicized (Burnet 2011; Oya 2013).

This mixed-method design involves a two-step course of action (Creswell and Clark 2011; Creswell 2014; Kuckartz 2014). In the first step, from November 2014 to May 2015, qualitative data in two districts of the Northern Province (Burera and Musanze) and Kigali were collected. This qualitative phase was divided into two parts, and purposive sampling was used in both phases. At the beginning of the data collection, fifteen interviews were conducted with central and local decentral government officers, leaders of agribusinesses and cooperatives, NGO members and academics. Additionally, two focus-group interviews with cooperative members were conducted. In this qualitative analysis, different employment categories became clearer. In the second part of the qualitative step, twenty-seven interviews with members of the different employment categories were conducted. All interviews have been transcribed and translated from Kinyarwanda to English (if necessary), then coded and categorized based on Grounded Theory with the software MaxQDA (Strauss and Corbin 1996). The results from the qualitative analysis have been integrated into the questionnaire of the second-step quantitative data collection. The sampling followed a multi-stage stratified random technique (Onwuegbuzie and Collins 2007). The survey villages and respondents were chosen randomly after stratification by district, sector, and cell. The survey was conducted in two phases in October 2015 and in three districts (Burera, Musanze, and Gakenke) in the Northern Province of Rwanda. This is the most productive agriculture zone (Republic of Rwanda 2015b) and the most densely populated area, with approximately 565 people per square kilometre (Republic of Rwanda 2015a). The districts are similar in terms of population characteristics, household size, and individual education level (Republic of Rwanda, 2012a). The three research sites were selected based on their levels of infrastructure, access to market, distance to the border, and the level of commercialization of agricultural production. They range from the wellconnected Burera along the border of Uganda, which has a greater share of market-oriented farmers, to the remote Gakenke, with limited paved roads where subsistence farming is predominant, to Musanze, which can be classified as somewhere between Burera and Gakenke. A total of 554 households were interviewed in the first part. In the second part of the survey, 567 male and female respondents were interviewed from 381 households. The quantitative data analysis was generated from a descriptive to interferential analysis. The Logit model was used to identify the drivers that lead to casual on-field agricultural work instead of self-employed farming. In this case, the dependent variable is binary, which makes the Logit regression model appropriate (Backhaus 2016). The Tobit regression model was employed to estimate the wage difference of casual on-field agricultural workers. Wage as a dependent variable is continuous and has an upper and decrease limit, which fits this model well (Tobin 1958). As 
a last step, evidence of the qualitative and quantitative results was analysed and interpreted together to arrive at a deeper understanding of the rural labour market and in order to contextualize the quantitative data (Creswell and Clark 2011).

\section{Results}

The aim of this chapter is to explain the rural labour market from different angles. The chapter is divided into four parts. The goal of the first part is to give a general picture of the productive labour market of the Northern Province of Rwanda and to illustrate changes through the process of agricultural transformation. With the help of a graphic representation, various employment categories are presented and analysed in terms of women's and men's representation. Casual on-field agriculture workers are the focus of the second and third part. The discussion concerns the drivers that influence this employment category and the working environment of casual on-field agricultural workers. The last part of this chapter is devoted to the topic of social transformation and the complexity of gendered roles at the community and household level. The quantitative and qualitative results interweave with each other, and qualitative quotations are also used to confirm quantitative findings.

\subsection{The big picture of the gendered rural labour market}

The rural labour market of the Northern Province of Rwanda is a composite of different employment categories. One major distinction is between employment within and outside agriculture and between skilled and unskilled labour. The following evidence-based map illustrates the different employment categories and the network including the various employment opportunities.

Figure 1. Map of the rural labour market, different employment categories within and outside agriculture

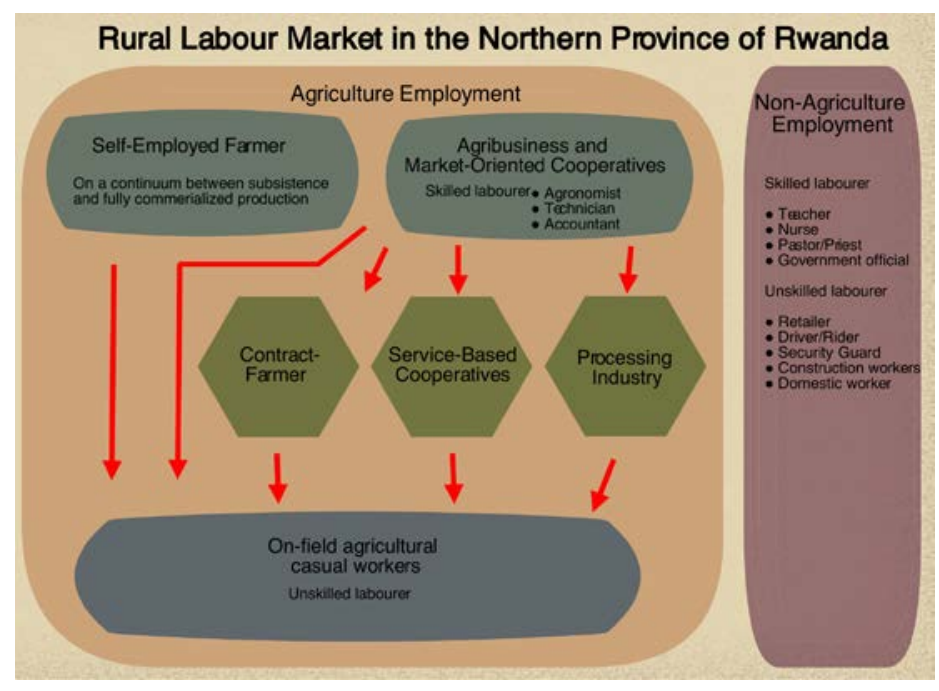


Overall, a segmented rural labour market was found where women are overrepresented in primary production and in low-paid employment. Drivers of the agriculture transformation are agribusiness and market-oriented cooperatives, which are mainly owned by Rwandans; international investors are absent in these three districts. Both are supported by the government, where employment is created almost exclusively in the informal sector. The main driver of this change could be individual commercialized farmers. The results show that the rural labour market is dominated by small-scale agriculture production. The majority (63.8 percent) of household heads, or 352 out of 551 households, specify their main occupation as self-employed farmers. On average, a household has 0.4 hectares of land, and nearly the whole plot is under crop production. Their market orientation is still at a low level because only 25 percent of households are commercialized, indicating that this proportion of self-employed farmers market half or more of their harvest. In three employment categories, feminization is found: selfemployed farmers, casual on-field agricultural workers, and domestic workers. By asking about the main employment of the household head and spouse, the figures show that approximately 60 percent of women and 40 percent of men are self-employed farmers. Casual on-field agricultural workers include 143 employees (14.5 percent), the second largest employment group. In this employment group, as seen in the first example, 60 percent of the casual on-field agriculture workers are women. Additionally, in the sample, 203 casual on-field agricultural workers report doing agricultural casual work in combination with subsistence farming, not as a main employment. The wages of agricultural casual workers are similar to those of domestic workers, the lowest in the rural labour market. Casual work outside agriculture, which is male dominated, earns double the wages of on-field agricultural workers. Domestic workers $(n=16)$ are hardly found in rural areas, but in the qualitative analysis, it appeared that contract farmers, who are the wealthiest farmers with more access to land, often employ at least one female domestic worker. Furthermore, agribusiness and market-oriented cooperatives are embedded in a network of various stakeholders similar to small cooperatives or contract farmers, which profit from spillover effects. These contract farmers or commercialized self-employed farmers employ casual onfield agricultural workers. During the past decade, so-called service-based cooperatives have been built. These cooperatives specialize in a specific task in the value chain. At the level of primary production, most women cooperatives manage the field work for an entire cultivation cycle. For packing, which is a better paying job, men's cooperatives take the lead. In this sphere of market-oriented agricultural production, a chain of employment has been established. Moreover, only a few employees work as agronomists, technicians, or accountants. Despite being skilled, they are mostly employed on demand. Employment outside the agriculture sector is marginal, and women are underrepresented. The data of 986 household heads and spouses show that only 14 women and 36 men work as casual workers in the non-agricultural sector and only 8 women and 13 men have formal employment.

Casual on-field agricultural workers play an important role in agriculture transformation. For this particular role, at the base of the value chain, more women than men are integrated. It is necessary to 
look closer at the data in the next chapter. First, we elaborate the factors that push people out of agriculture into casual on-field agricultural work; second, we analyse their working environment and wages; and third, we include an analysis of unpaid work.

\subsection{Diverse drivers to do casual on-field agricultural work}

With the survey data, we used a Logit Model to identify factors that favour casual on-field agricultural work as a main source of employment compared to self-employed farming. Among the various explanatory variables, land sizes, degrees of commercialization, location, household size, gender, and age had a significant correlation with casual on-field agricultural work (Table 1). No significant correlation was found between casual on-field agricultural work and education or marital status. The following chapter explains the different significant variables that drive casual on-field agricultural work and interweave these quantitative results with qualitative data.

\subsubsection{Access to land}

Land size and casual on-field agricultural work were negatively correlated. The lack of land is one of the main drivers for such employment. Casual on-field agricultural workers often own a small piece of land, but it is not sufficient to cover their daily needs for the whole year. Annabelle, a widow with five children, offers deeper insight into how access to land influences the employment categories and the wealth status of a household.

"I do not have a farm; it is just a small piece of land on which we live. We live in poverty." (Annabelle, 40 years old, casual on-field agricultural worker)

Not only are female-headed households affected by land constraints, but the dual-headed households also face the same challenge. Pascal is married, a father of three children, and pursues casual on-field agricultural work in Kinigi. He explained his motivation for doing casual on-field agricultural work in an interview:

"For me, I have the small plot that I received from my parents. I do not yet have the means to buy another piece of land. The one I have, I cultivate it for home consumption, and when food is consumed, I go and work for others until the new crop grows again.” (Pascal, 27 years old, casual on-field agricultural worker)

Pascal's statement shows the relationship between access to land and food security. Land scarcity, in combination with the on-going population growth, was discussed during a focus group interview with an agricultural cooperative. David, a cooperative member, interprets the current situation: 
"The land is not sufficient for the population because the land does not change, but the population grows every year.” (David, 52 years old, self-employed farmer)

The data show that land is not equally distributed between the different employment groups. Casual onfield agricultural workers have limited access to land as they own 0.1 hectares on average, compared to self-employed farmers who hold an average of 0.5 hectares of land. Surprisingly, the employment group with the best access to land, with 1.5 hectares, are the households where the household head has formal employment and is not reliant on natural resources ${ }^{4}$. However, only 19 household heads have obtained formal employment. This result must be considered critically. This figure has limitations, but it is nonetheless important to recognize that households that are not chiefly dependent on agriculture have the most access to land.

Table 1. Logit Model of probability to be employed for casual on-field agricultural workers

Access to land is linked with household food security and wealth and is an important factor in the occurrence of agricultural casual work. The availability of land shapes the rural labour market, but there are still other factors that increase the possibility of being an agricultural casual worker.

\subsubsection{Commercialization of agricultural production and access to the market}

Coupled with access to land, the statistics show that more commercialized households are less likely to do casual on-field agriculture work. Casual on-field agriculture workers are more subsistence-oriented compared to groups of self-employed farmers. They sell an average of 15 percent of their harvest, while self-employed farmers sell 27 percent. On the other hand, location is an important factor. People from Burera are more likely to do casual on-field agricultural work than people from Musanze. Eighty-three percent of all casual on-field agriculture workers (main and supplementary employment) are located in Burera, where the infrastructure is better and the border to Uganda is closer. Because of the small number of casual on-field agricultural workers $(n=24)$, the remote and poorly accessible Gakenke was not included in the model. Burera also leads in terms of employment creation. During the last ten years, 154 people began work as casual on-field agricultural workers in Burera, while in Musanze, only 23 people started work, and in Gakenke, only 14 people. Due to the short distance to the Ugandan border, casual on-field agricultural workers migrate to Uganda on a daily basis. Fifty agricultural casual workers from Burera crossed the border over the last 12 months in Uganda to take up employment. More men (n=46) than women $(\mathrm{n}=4)$ crossed the border.

Aside from these structural characteristics, other social factors drive people to do casual on-field agricultural work.

\footnotetext{
${ }^{4}$ In the collected data set, no data are available that allows an assessment on the use of this land.
} 


\subsubsection{Social characteristics and casual on-field agricultural work}

Two social characteristics influence the participation of household members in casual on-field agricultural work. Household size and casual on-field agricultural work are positively correlated, as is gender. A larger household is more likely to perform casual on-field agricultural work. For every additional household member, the probability of casual on-field agriculture work increases by approximately 1.12 percent, holding all other factors constant at their mean. In addition, compared to men, women have a 0.05 percent higher probability of participating in casual on-field agricultural work. A negative correlation was found between age and casual on-field agriculture work. Younger people are more likely to do this type of work. The average age of the casual on-field agricultural worker is 32 years, which is 10 years younger than the average age of the entire sample. Moreover, the education level of agricultural casual workers is low. Only three persons attended secondary school, and none of the casual on-field agricultural workers obtained an education above the secondary level. Among the workers, 38.3 percent cannot read and write. In the overall employment group, the level of education of women is lower than that of men. Twice as many men as women have a formal education. In the employment group of casual on-field agricultural workers, the share of women without formal education is even higher.

In summary, casual on-field agricultural workers are more likely to be female and young, have a low education level, and come from larger and subsistence-oriented households with limited access to land. The next chapter discusses the working environments of casual on-field agricultural workers and illustrates the precarious working conditions for women and men and the disadvantages for women in this particular sector.

\subsection{Working environment of casual on-field agricultural workers}

The working environment of casual on-field agricultural workers is characterized by informality and uncertainty. It can be seen from the figures that nearly all (99 percent) of the casual on-field agricultural workers are employed by individuals without any written contract; 76.9 percent are employed on an irregular basis with an oral contract or on demand, and only 23.1 percent work under a regular oral contract. They are employed nearly exclusively on a daily basis (98 percent). Only 2 percent are employed seasonally. Most of the workers start their work at 7 am and finish between $1 \mathrm{pm}$ and $3 \mathrm{pm}$ in the afternoon. In terms of the average working hours per day (7.3 hours), no gender differences were found. People with no regular oral contract congregate before $7 \mathrm{am}$ at a specific place where job seekers and employers meet. These precarious working conditions become apparent in the focus group discussion. Yvonne, a self-employed farmer and mother of three, frequently does casual on-field agriculture work asides from work on her own farm and reproductive work. She explains: 
"There is a place where women sit and wait for work; some big farm owners come and take the workers. When a woman waits and does not find a job, she goes back home and works on her own farm." (Yvonne, 31 years old, self-employed farmer)

In addition to this unstable and insecure employment, casual on-field agricultural workers also face wage differences for the same work. The evidence from this study suggests that only two variables influence the wages of casual on-field agricultural workers. The statistics show a significant relationship between wage and distance to the road, as well as gender.

Table 2. Factors influencing the wages of casual on-field agricultural workers

People who live more than 30 minutes from the nearest road earn approximately 80 Rwandan Francs ${ }^{5}$ (RWF) per day less than people who live within a 30-minute distance from the nearest road, holding all other factors constant. This finding reinforces the importance of accessibility and infrastructure.

Furthermore, a strong and positive correlation was found between gender and wage. The daily salary of a casual on-field agricultural worker ( $\mathrm{n}=341)$ is 800 Rwandan Francs (RWF) on average. Women earn an average of $730(S D=138)$ RWF and men earn 900 RWF (SD=244). This means that for the same work, women earn 19 percent less. The gender-wage gap is also visible by taking into account working hours. For seven hours of casual on-field agricultural work ( $n=99)$, women earn 720 RWF (SD=180) while men earn 870 RWF, resulting in a gender-wage gap of 20 percent. The gender-wage gap (30 percent) is even wider if only casual on-field agricultural workers who work eight hours per day are considered (Figure 2). Thus, spending more time in casual on-field agricultural work does not change the situation.

Figure 2. Gender-wage gap of casual on-field agricultural workers. Daily salary for women and men for seven and eight working hours per day.

Agribusiness leaders reported that women and men are paid equally. In a focus group discussion with cooperative members, the participants clearly note the gender-wage gap:

"When the husband is there, he also works, in fact, we all work. If I come home, I have 700 RWF; he comes home with 1000 RWF." (Christine, 48 years old, self-employed farmer)

On average, women and men are employed thirteen days per month. The difference in income between women and men is 2221 RWF per month. Specifically, this means that women have to work approximately 3 days more per month to earn the same income as their male counterparts. In addition,

\footnotetext{
${ }^{5} 1$ USD equivalent of approximately 774 Rwandan Franc (October 2016 OANDA)
} 
women spend fewer days per month on other people's fields than men. Women participate 11 days per month and men 15 days per month on average. However, both work an average of six months per year.

With this in mind, it is important to examine the reasons employers $(\mathrm{N}=164)$ say they prefer to work with women. The data show that 44.5 percent of employers prefer to work with women because they define casual on-field agricultural work as a woman's task and 18.9 percent want women workers because women will accept a smaller salary. Other reasons stated are that women perform better (15.8 percent), it is easier to work with women (15.8 percent), and women work harder (5 percent).

During the qualitative interviews, gendered tasks - or rather, the gendered labour market - was visible. Employment in the processing sector was reserved for men, manifested with the argument that processing work need physical force. Furthermore, there are wage disparities between the different employment groups. Employees in the processing industry, who work on a daily basis, earn 2000 RWF per day on average.

Another key element is that women are much more involved in child care, and this hinders women's participation in paid employment. The data show that women's potential to shift the child's care to another person or institution during their work time outside the farm is limited. Women mostly work during the time the children attend school (32 percent) or they leave the children alone at home (23 percent) or with other household members (23 percent), but generally not with the father. Domestic workers and neighbours ( 7 percent) and fathers ( 2 percent) play a subordinate role in a child's care. Likewise, women face difficulties finding work or bargaining for a matched salary because of their role in reproduction. Thus, 70.8 percent $(\mathrm{N}=119)$ of households that employ casual workers $(\mathrm{N}=168)$ would not employ a woman if she is pregnant, and 37 percent $(\mathrm{N}=62)$ would not employ a woman if she takes the baby with her to the workplace. One individual employer explained this during the interview:

"For me, when I recruit, I chose men because they are strong. For women, I choose those without a baby on her back because the baby will take some of her time. Even pregnant women are not preferred because they are weak.” (Marie-Louise, 27 years old, self-employed farmer and cooperative member)

Discrimination of women is not only seen on the employer side. A similar picture is found on the employees' side. The respondents were asked if it is more difficult for a woman to find work if she is pregnant or carrying a baby: 81.8 percent find it harder or much harder to find a job during pregnancy, and 70.9 percent of the time, a woman takes her baby with her to work. The presence of a baby could also influence the daily salary. A woman from the same focus group mentions that a female worker earns less if she takes her child to the work place. Zipola, a single mother with a two-year-old boy, performs casual on-field agricultural work as her main employment. She describes how she loses bargaining power if she takes the baby to her working place: 
“When you have a child with you, you are paid less than 700 Rwandan Francs.” (Zipola, 23 years old, casual on-field agricultural worker)

Precarious employment situations and the life situations of these women affect their employment. This is shown by the following figures concerning the time spent at home after giving birth. Two weeks after giving birth, 20 percent of women return to their paid activities outside the farm, and 56.8 percent return to work after 4 weeks. Collectively, 62.3 percent and 81.6 percent return after 6 weeks and 8 weeks, respectively. Because of the informality of agricultural casual work, the employees are not protected by the labour law. The burden of child care is crucial for women who participate in the paid informal labour market. Alphonsia, a female casual on-field agricultural worker, works to secure her household's livelihood. She explains how she manages the difficulty of combining productive and reproductive work:

"For me, when I have a baby and I want a job, I go with another young child who will be caring for the baby while I am working.” (Alphonsia, 38 years old, casual on-field agricultural worker)

These results show a feminization of agriculture as well as a feminization of responsibility and obligations. Women play an important role in the paid and unpaid rural labour market while carrying the main bulk of reproductive work; they also have to work under precarious working conditions for low wages. Women and men do not have the same preconditions when they participate in the paid labour market. Thus, the participation of women in this informal labour market increases their responsibilities under less remunerative conditions. This confirms the data for time use, which are discussed in the next part of the paper. Furthermore, the current transformation of agriculture is carried out on women and subsistence-oriented farmers.

\subsection{Social transformation or adherence at the community and household levels}

The evidence from this study suggests a variety of factors that influence the process of social transformation. As outlined above, economic transformation is ongoing, and this also influences social transformation. Women report that their integration into the paid labour market empowers them in terms of decision-making in the household and cooperatives, and their self-confidence increases. On the other hand, their daily duties also increase, and a feminization of responsibilities and obligations is visible. Thus, 50.8 percent of the respondents who work outside their homes note that the daily duties of women have increased. Only 34.3 percent mention that the work load is the same, and for 14.9 percent, the duties decreased. The time-use data shows that the traditional division of labour still exists: men are more involved in income-generating activities, and women are more involved in care and domestic work. In the data, the respondents' time use is divided into four groups: income-generating activities (farming, self-employment, and work as employee), reproductive work (care for children/adults/elderly, domestic work such as fetching water and wood, cooking, shopping, textile care), leisure time (listening 
to the radio, reading, and exercise), and social activities. Women spend approximately four hours on income-generating activities and four and a half hours on reproductive work daily. Per day, men spend one hour and 40 minutes more than women on income-generating activities and nearly three hours less on reproductive work. Moreover, men have more leisure time and more time for social activities. This means that men have more time to recover from their daily duties and maintain their social network. The available data show the work burden of women, and they are placed in ready-made roles. The data show no statistically significant difference in time spent on reproductive work between the employment categories of casual on-field agricultural workers and subsistence farmers.

Furthermore, gender inequality in reproductive work was also described indirectly during the qualitative interviews. Initially, women and men described their living together in a household as harmonious and that the husband and wife work and make decisions together. This leads to a presentation of ideal circumstances in their own household. However, the respondents often talked about their neighbours as “other” people. By using this word "other," they highlight the gender imbalance between women and men, especially relating to the division of labour and decision making. Solange, married with five children, secures a livelihood in self-employed farming with her husband. She explains:

"Gender equality in my village is very low. You can see it in some households where a man can make a decision without discussing it with his wife. The man calls a truck and sells Irish potatoes without informing his wife about the quantity they harvested. You understand that there is no gender equality." (Solange, forty-eight years old, self-employed farmer)

The analysis of the interviews also shows that gender equality is often linked to the fact that women can participate in work previously reserved for men outside the household, as well as the fact that unpaid care or housework is not shared. Men are likely to take over care or housework only if female household members are absent or ill.

The roles of women and men are constructed differently in rural Rwanda, and these roles are rooted in a patriarchal way of thinking, which leads to the traditional division of labour. Rwanda has a good gender policy on the national level for formal employment, but persistent gender discrimination still exists in the rural labour market and at the community and household levels. Policy is missing or is not clear with regard to informal and agricultural casual employment. Hence, in this area of the labour market, protections and rights are not really being enforced.

\section{Discussion}

The main purpose of the paper was to provide a gender perspective on the rural labour market in Rwanda, thus contributing to the ongoing feminization debate. Three scientific feminization debates provide a suitable background to embed the empirical findings. However, the feminization debates must be 
considered critically. From the results presented in the paper, the rural labour market in the Northern Province of Rwanda is gendered. More women than men are found in all three employment categories: subsistence farmers, casual on-field agricultural workers, and domestic workers.

Here, on the one hand, the feminization of labour in the agriculture sector is visible, and the results can be embedded into the existing literature. The view that the transformation of agricultural is linked with a feminization of labour, especially low-paying jobs, is in line with the results of a recent book from Learch (2016). Doss (2011) also characterizes the rural labour market as a sector where women are overrepresented in part-time, seasonal, and unpaid work. In terms of working conditions, the data broadly consist of studies carried out on the non-traditional, transitional agricultural export sector in East Africa, where a gender-wage gap and low earnings were found in addition to precarious working conditions (Maertens and Swinnen 2012; Razavi 2009; Barrientos, Dolan and Tallontire 2003; LastarriaCornhiel 2006). According to a study by Rizzo (2011), casual on-field agricultural workers in rural Rwanda are the poorest population group of the society and therefore are not profiting from the current agricultural policies. This picture can be confirmed by the data presented: casual on-field agricultural workers define themselves as poor and are nearly landless. Self-employed farmers with small plots are not benefiting like farmers with medium and larger pieces of land, which increase disparities on a local level (Cioffo, Ansoms and Murison 2016; Dawson, Martin and Sikor 2016; Clay 2017). In addition, Ansoms (2011) notes that the population growth has increased the demand for land and that farmers with poor access to land risk leaving the agricultural sector. The labour market is slow to reflect and include landless people in its calculations.

On the other hand, the general assumption of feminization of agriculture does not fully fit. There are employment categories in agriculture that are still male dominated, such as contract farming or labour in the agricultural processing industry. Both are financially more attractive, and greater access to land is assumed. Additionally, the employment category of domestic worker is not directly related to the agriculture sector. The common feature of the three feminized categories is low earnings. It is not clear whether women find employment only in low-earning positions or if a higher percent of women in a specific employment group generally decreases the earnings.

The third debate about the feminization of responsibilities and obligations, indicated mainly by the work of Chant (2014), can be supported with the available results. Chant's study shows that female wage workers are included in the transformation of agriculture, but their burden of unpaid care and domestic work has not been reduced, thus leading to a feminization of responsibility and obligations. Leach (2016) and Razavi et al. (2012) note that, generally, reproductive work is consistently ignored and undervalued even when this work is essential to the wealth of societies and to reproduce labour force capital. Debusscher and Ansoms (2013) contend that Rwandan women are negatively affected by the transition 
from subsistence to market-oriented agriculture production, mainly in the context of intra-household relations and the fact that care work is not recognized or valued by the government. This development risks becoming socially unsustainable (Learch 2016). Razavi et al. (2012) and Doss (2011) link the labour market with the role of women in the society and argue that women, through their reproductive role, do not experience the same changes in the labour market. In the study by Ansoms et al. (2017), the mismatch between the macro-level statistical analysis on Rwandan livelihoods and the results from indepth field research is explained. The same incongruence was found in this study between the macrolevel gender analysis with the gender gap index and the micro-level analysis at the household level. Women articulated their subordinate role at the household level and their discrimination in terms of wages as casual on-field agricultural workers. The FAO (2010) describe the gender dimension of agricultural and rural development as a gender gap in earnings and mention a lack of genderdisaggregated data from the agricultural sector. With this study, a step to fill the gap was made.

\section{Conclusion}

The rural labour market in the Northern Province of Rwanda is characterized by self-employed farmers and precarious on-field agricultural employment. Formal employment or employment outside agriculture is marginal, and women are underrepresented. Gender and access to land shapes the labour market and influences the wealth and food security situation of a household. Lack of landholding and low market-oriented production as well as low education levels and household size force people to work on wealthier farmers' fields. For women, it is generally the only opportunity to earn money outside their own farms. Younger people, especially those pushed out of self-employed farming, attempt to secure livelihoods with casual on-field agricultural work, but the rural labour market is not prepared for young job seekers. The chosen holistic approach demonstrates that women are self-employed farmers. However, despite being part of the paid labour market, they shoulder the overwhelming share of child care and domestic work. Reproductive work is a particular detriment for women in finding decent work. Women have limited alternatives to shift care work to other institutions or family members, especially before children are enrolled in school. This weakens their bargaining power as well as their mobility, and they have to work for decreased wages. This is also reflected in the gender-wage gap. Progressive Rwandan policies and laws encourage women to be part of the paid labour market, but only women with formal employment, living mostly in urban areas, are able to profit from them. A good example of this is maternity leave. Women in rural areas return to work shortly after giving birth; this is interpreted as a sign of poverty and precarious life situations. How the different employment groups, genders, and age factors influence asset creation and wellbeing and how certain employment is a path out of poverty must be part of a further investigation. 
Rwanda is robust in terms of agricultural policies, which interfere with increased productivity and gender equality. Progressive gender policies are a good step to attaining gender equality within the country, but there is still imbalance between the national level and the community and household level. The policies do not reach the grassroots level, and the implementation appears to be difficult. Furthermore, agriculture policies, which are implemented through cooperatives, push agricultural transformation and generate more crop output. However, poorer farmers are side-lined and have to seek paid employment in an imperfect labour market, which leads women in particular into precarious life situations. 


\section{References}

Ansoms, A. 2007. Striving for growth, bypassing the poor? A critical review of Rwanda's rural sector policies. Institute of Development Policy and Management Discussion Paper 2007.02. Antwerp: University of Antwerp.

Ansoms, A. 2010. Views from Below on the Pro-Poor Growth Challenge: The Case of Rural Rwanda. African Studies Review 53(2): 97-123.

Ansoms, A. and K. Claessens. (eds.). 2011. Natural Resources and Local Livelihoods in the Great Lakes Region of Africa: A Political Economy Perspective. London: Macmillan Palgrave.

Ansoms, A. and D. Rostagno. 2012. Rwanda's Vision 2020 halfway through: what the eye does not see. Review of African Political Economy 39(133): 427-450.

Ansoms, A., E. Marijnen, G. Cioffo and J. Murison. 2017. Statistics versus livelihoods. Questioning Rwanda’s pathway out of poverty. Review of African Political Economy 44 (151), S. 47-65.

Antonites, A. J. and J.J. Haguma. 2011. Assessing the innovative nature of the agricultural based small businesses in Rwanda - The case study of the coffee industry. African Journal of Agricultural Research 6(3): 757-770.

Ayalew, A. D., K. Deininger and M. Goldstein. 2014. Environmental and gender impacts of land tenure regularization in Africa: Pilot evidence from Rwanda. Journal of Development Economics 1(110): 262-275.

Backhaus, K. (eds.). 2016. Multivariate Analysemethoden: Eine anwendungsorientierte Einführung (14th ed.). Berlin: Springer Gabler.

Barrientos, S., C. Dolan and A. Tallontire. 2003. A Gendered Value Chain Approach to Codes of Conduct in African Horticulture. World Development 31(9):1511-1526.

Barrientos, S., N. Kabeer and N. Hossain. 2004. The gender dimensions of the globalization of production. Policy Integration Department World Commission on the Social Dimension Working Paper No. 17. Geneva: ILO.

Bauer, G., and J. E. Burnet 2013. Gender quotas, democracy, and women's representation in Africa: Some insights from democratic Botswana and autocratic Rwanda. Women's Studies International Forum 41:103-112.

Booth, D. and F. Golooba-Mutebi. 2014. Policy for agriculture and horticulture in Rwanda: A different political economy? Development and Policy Review 32(2): 173-196.

Boserup E. (1970). Women's Role in Economic Development. Reprinted with new Introduction in 2011. United Kingdom, United States of America: Earthscan. 
Brauw, A., V. Mueller and H. L. Lee. 2014. The Role of Rural-Urban Migration in the Structural Transformation of Sub-Saharan Africa. World Development 63: 33-42.

Burnet, J. E. 2011. Women Have Found Respect: Gender Quotas, Symbolic Representation, and Female Empowerment in Rwanda. Politics \& Gender 7(03): 303-334.

Chant, S. 2006. Re-thinking the "Feminization of Poverty" in Relation to Aggregate Gender Indices. Journal of Human Development 7 (2): 201-220.

Chant, S. and Sweetman C. 2012. Fixing women or fixing the world? 'Smart economics', efficiency approaches, and gender equality in development. Gender \& Development 20 (3): 517-529.

Chant, S. 2010. Gendered poverty across space and time: introduction and overview. In: Sylvia Chant (Hg.): The International Handbook of Gender and Poverty. Concepts, Research, Policies. Glos: Edward Elgar Publishing Limited, S. 1-26.

Chant, S. 2014. Exploring the "feminization of poverty" in relation to women's work and home-based enterprise in slums of the Global South. International Journal of Gender and Entrepreneurship 6 (3): 296-316.

Cioffo, G. D., A. Ansoms and J. Murison. 2016. Modernising agriculture through a 'new' Green Revolution. The limits of the Crop Intensification Programme in Rwanda. Review of African Political Economy 43 (148): , S. 277-293.

Clay, N. 2017. Agro-environmental Transitions in African Mountains. Shifting Socio-spatial Practices Amid State-Led Commercialization in Rwanda. Annals of the American Association of Geographers 107 (2): 360-370.

Creswell J. 2014. Research Design: Qualitative, Quantitative, and Mixed Methods Approaches (4th ed). Los Angeles: SAGE.

Creswell J. and V. L. P. Clark. 2011. Designing and Conducting Mixed Methods Research (2end Edition). California: SAGE Publications Ldt.

Dawson, N., A. Martin and T. Sikor. 2016. Green Revolution in Sub-Saharan Africa. Implications of Imposed Innovation for the Wellbeing of Rural Smallholders. World Development 78: 204-218.

Debusscher, P. and A. Ansoms. 2013. Gender Equality Policies in Rwanda: Public Relations or Real Transformations? Development and Change 44(5): 1111-1134.

Deere, C. and C. Doss, C. 2006. The Gender Asset Gap: What Do We Know and Why Does It Matter. Feminist Economics 12 (1-2): 1-50.

Detraz, N. (2017): Gender and the Environment. Cambridge: Polity Press.

Diao, X., P Hazell and J. Thurlow, James. 2010. The Role of Agriculture in African Development. World Development 38 (10): 1375-1383. 
Doss, C. 2002. Men's Crops? Women's Crops? The Gender Patterns of Cropping in Ghana. World Development 30 (11): 1987-2000.

Doss, C. 2011. The role of women in agriculture. ESA Working Paper No 11-02. Rome: The Food and Agriculture Organization of the United Nations.

Food and Agricultural Organization (FAO) and International Fund for Agricultural Development and International Labour Office. 2011. Gender dimension of agricultural and rural employment: Differentiated pathways out of poverty: Status, trends and gaps. Rome: FAO and International Fund for Agricultural Development and ILO.

Golub S., J. McManus S. College. 2008. Horticulture Exports and African Development. Paper prepared for United Nations Conference on Trade and Development.

Government of Rwanda (GoR). 2008. Law N59/2008 On the Prevention and Punishment of GenderBased Violence. Kigali: GoR.

Government of Rwanda (GoR). 2009. The Constitution of the Republic of Rwanda. Official Gazette of the Republic of Rwanda on $4^{\text {th }}$ June 2003. Kigali: GoR.

Government of Rwanda (GoR). 2009b. Law regulating labour in Rwanda. Official Gazette of the Republic of Rwanda Year $48 \mathrm{n}^{\circ}$ special of 27 May 2009. Kigali: GoR.

Government of Rwanda (GoR). 2015. Cabinet Approves Bill to Grant 100\% payment to Mothers on Maternity Leave. Government of Rwanda.

http://www.gov.rw/news_detail/?tx_ttnews\%5Btt_news\%5D=1130\&cHash=349b9d7e7dd4f8c0e7 b8cfd51c8f816c. Access 30 April 2016.

Headey, D. D. and T.S. Jayne. 2014. Adaptation to land constraints: Is Africa different? Food Policy 48:18-33.

Holden, S. T. and K. Otsuka. 2014. The roles of land tenure reforms and land markets in the context of population growth and land use intensification in Africa. Food Policy 48: 88-97.

Huggins, C. D. 2014a. Control Grabbing' and small-scale agricultural intensification: emerging patterns of state-facilitated 'agricultural investment' in Rwanda. The Journal of Peasant Studies 41(3): 365384.

Huggins, C. D. 2014b. Land Grabbing \& Land Tenure Security in Post-Genocide Rwanda. In Ansome A and Hilhorst T. ed. Losing Your Land, 141- 162. Dispossession in the Great Lakes. Suffolk: James Currey. 
International Labour Organization (ILO). 2010. Women in labour markets. Measuring progress and identifying challenges. Geneva: ILO.

International Labour Organization (ILO). 2016. Women at Work. Trends 2016. Geneva: ILO.

Jayne, T., J. Chamberlin and D.D. Headey 2014. Land pressures, the evolution of farming systems, and development strategies in Africa: A synthesis. Food Policy 48: 1-17.

Jervem, M. 2013. Poor Numbers: How we are misled by African development statistics and what to do about it. United States of America: Cornell University Press.

Kabeer, N. 2012. Women's economic empowerment and inclusive growth: labour markets and enterprise development. SIG Working Paper 2012/1. London: School of Oriental and African Studies.

Kabeer N. and L. Natali. 2013. Gender Equality and Economic Grow: Is there a Win Win?. IDS Working Paper Volume 2013 No 417. London: Institute of Development Studies.

Kuckartz, U. 2014. Mixed Methods: Methodologie, Forschungsdesigns und Analyseverfahren. Wiesbaden: Springer VS.

Lastarria-Cornhiel, S. 2006. Feminization of Agriculture: Trends and Driving Forces. Background Paper for the World Development Report. University of Wisconsin-Madison: Latin American Centre for Rural Development.

Leach, M. (Hg.). 2016. Gender Equality and Sustainable Development. Pathways to Sustainability. New York: Routledge.

Lund, C. 2016. Rule and Rupture. State Formation through the Production of Property and Citizenship. Development and Change 47 (6), S. 1199-1228.

Maertens, M. and J. F.M. Swinnen. 2012. Gender and Modern Supply Chains in Developing Countries. The Journal of Development Studies 48(10): 1412-1430.

McLanahan, S., E. L. Kelly. 2006. The Feminization of Poverty. In: Janet Salzman Chafetz (Hg.): Handbook of the Sociology of Gender. USA: Springer.

Momsen, J. D. (Hg.). 2008. Gender and Development. Critical Concepts in Development Studies. Oxon: Routledge (Volume 1 Theory and Classics).

National Agricultural Export Development Board (NAEB). 2015. Annual Report 2014-2015. Kigali: NAEB.

National Agricultural Export Development Board (NAEB). 2013. Statistics 2013 on Tea, Coffee and Horticulture. Kigali: NAEB 
National Institute of Statistics of Rwanda (NISR). 2014. Fourth Population and Housing Census, Rwanda, 2012. Labour force participation. Thematic Report. Kigali: NISR.

OANDA. 2016. Währungsrechner. https://www.oanda.com/lang/de/currency/converter/. Accessed 18 October 2016.

Onwuegbuzie, A. J., and K. M. T. Collins. 2007. A Typology of Mixed Methods Sampling Designs in Social Science Research. The Qualitative Report Volume 12(2): 281-316.

Oya, C. 2013. Methodological reflections on land grab databases and the land grab literature rush. Journal of Peasant Studies 40(3): 503-520.

Oya, C. and; N. Pontara. 2015. Introduction. Understanding rural wage employment in developing countries. In C. Oya, N. Pontara, ed. Rural Wage Employment in Developing Countries. Theory, evidence, and policy, 171-204. New York: Routledge.

Pearce, D. 1978. The Feminization of Poverty: Women, Work, and Welfare. The Urban \& Social Change Review 11 (1/2): 28-36.

Razavi, Shahra (eds.). 2009. The Gendered Impacts of Liberalization: Towards Embedded Liberalism? Geneva: United Nations Research Institute for Social Development (UNRISD).

Razavi, Shahra. 2011. Agrarian debates and gender relations: Now you see them, now you don’t. Du grain à moudre. Genre, développement rural et alimentation, 47-58.

Razavi, S., C. Arza, E. Braunstein, S. Cook and K. Goulding. 2012. Gendered Impacts of Globalization. Employment and Social Protection. United Nations Research Institute for Social Development Gender and Development Research Paper No. 16. Geneva: United Nations Research Institute for Social Development.

Republic of Rwanda. 2000. Vision 2020. Kigali: Ministry of Finance and Economic Planning.

Republic of Rwanda. 2012a. Characteristics of households and housing: Fourth Population and Housing Census, Rwanda, 2012 Thematic Report. Kigali: National Institute of Statistics of Rwanda.

Republic of Rwanda 2012b. Farm Land Use Consolidation in Rwanda: Assessment from the perspectives of agriculture sector. Kigali: Ministry of Agriculture and Animal Resources.

Republic of Rwanda 2013a. Economic Development and Poverty Reduction Strategy II (EDPRS2): 2013 - 2018. Kigali: Ministry of Finance and Economic Planning.

Republic of Rwanda. 2013b. Strategic Plan for the Transformation of Agriculture in Rwanda Phase III. Kigali: Ministry of Agriculture and Animal Resources. 
Republic of Rwanda. 2015a. District Profile: Musanze. Kigali: National Institute of Statistics of Rwanda.

Republic of Rwanda. 2015b. Rwanda Poverty Profile Report 2013/2014: Integrated Household Living Conditions Survey (EICV). Kigali: National Institute of Statistics of Rwanda.

Perrons, D. 2015. Gendering the inequality debate. Gender \& Development 23(2): 207-222.

Petit, N. and M. Rizzo 2015. The policy neglect of rural wage employment. The cases of Rwanda and Ethiopia. In C. Oya, and N. Pontara, ed. Rural Wage Employment in Developing Countries. Theory, evidence, and policy, 171-204. New York: Routledge.

Rizzo M. 2011. Rural wage employment in Rwanda and Ethiopia: A review of the current policy neglect and a framework to begin addressing it. Policy Integration Department Working Paper. Geneva: International Labour Office.

Pritchard, M. F. 2013. Land, power and peace: Tenure formalization, agricultural reform, and livelihood insecurity in rural Rwanda. Land Use Policy 30(1):186-196.

Sharlach, L. 1999. Gender and genocide in Rwanda: Women as agents and objects of Genocide. Journal of Genocide Research 1(3): 387-399.

Siegmann, K. A. and F. Schiphorst. 2016. Understanding the globalizing precariat: From informal sector to precarious work. Progress in Development Studies 16(2): 111-123.

Strauss, A. L. and J. Corbin. 1996. Grounded Theory: Grundlagen Qualitativer Sozialforschung. Weinheim: Beltz Psychologie Verlags Union.

Tejani S. and M. Milberg. 2016. Industrial Upgrading and Manufacturing Employment in Developing Countries. Feminist Economics 22(2): 24-54.

Titeca K. and C. Kimanuka 2012. Walking in the dark. Informal cross-border trade in the great lakes region. International Alert and UN Women.

The International Fund for Agricultural Development. 2011. Republic of Rwanda Project for Rural Income Thorugh Exports (PRICE). African II Division Programme Management Department Project Design Report Volume II. The International Fund for Agricultural Development.

Tobias, J., J. Mair and C. Barbosa-Leiker. 2013. Toward a theory of transformative entrepreneuring: Poverty reduction and conflict resolution in Rwanda's entrepreneurial coffee sector. Journal of Business Venturing 28(6): 728-742.

Tobin, J. 1958. Estimation of Relationships for Limited Dependent Variables. The Econometric Society 26(1): 24-36.

United Nation Conference on Trade and Development. 2014. Who is Benefiting from Trade Liberalization in Rwanda? A Gender Perspective. Division on International Trade in Goods and Services, and Commodities. Geneva: United Nations Conference on Trade and Development. 
United Nations. 2015. Transforming our World: The 2030 Agenda for Sustainable Development. New York: United Nations.

United Nation Comtrade and United Nation Trade Service. 2015. Rwanda. 2013: International Trade Statistics Database. United Nation Comtrade and UN Service Trade.

United Nations Economic and Social Council (ECOSOC). 1997). Coordination of the policies and activites of the specialized agencies and other bodies of the United Nations Systems. Mainstreaming the gender perspective into all policies and programmes in the United Nations system. Coordination Segement.

van Damme, J., A. Ansoms; and P.V. Baret. 2014. Agricultural innovation from above and from below: Confrontation and integration on Rwanda's Hills. African Affairs 113 (450), S. 108-127.

Verhofstadt, E. and M. Maertend. 2014. Smallholder cooperatives and agricultural performance in Rwanda: do organizational differences matter? Agricultural Economics 45(S1): 39-52.

Verhofstadt, E. and M. Maertens. 2015. Can Agricultural Cooperatives Reduce Poverty? Heterogeneous Impact of Cooperative Membership on Farmers Welfare in Rwanda. Applied Economic Perspectives and Policy 37(1): 86-106.

World Bank. 2009. Gender in Agriculture Sourcebook. Washington: The International Bank for Reconstruction and Development/World Bank.

World Bank. 2013. Rwanda Economic Update: Maintaining the Momentum with a special focus on Rwanda's pathway out of poverty. 4th Edition. Kigali: World Bank.

World Bank. 2016a. World Development Indicators: Rural environment and land use: Environment. http://wdi.worldbank.org/table/3.1\# (accessed 22 October 2016).

World Bank. 2016b. Rwanda. http://data.worldbank.org/country/rwanda. Accessed 22 October 2016).

World Bank. 2016c. GDP growth (annual \%): Rwanda. http://data.worldbank.org/indicator/NY.GDP.MKTP.KD.ZG. Accessed 22 October 2016.

World Economic Forum. 2016. The Global Gender Gap Report 2016: Insight Report. Geneva: World Economic Forum.

World Economic Forum. 2015a. The Global Gender Gap Report 2014: Insight Report. Geneva: World Economic Forum.

World Economic Forum. 2015b. The Global Gender Gap Report 2015: Insight Report. 10th Anniversary Edition. Geneva: World Economic Forum. 